\title{
Hydroxybenzoate magnesium analogues induced apoptosis in HT-1080 human fibrosarcoma cells
}

\author{
Abigail J Manning ${ }^{1}$, Eamon J Mahdi ${ }^{2}$, Andrea GS Pepper ${ }^{3}$, Chris Pepper ${ }^{3}$, Nawal M Al-Musayeib ${ }^{4}$ and Jassem G Mahdi ${ }^{*}$ \\ ${ }^{1}$ University Hospital of Wales, Cardiff, UK \\ ${ }^{2}$ Cardiff School of Medicine, Cochrane Medical Education Centre, Heath Park, UK \\ ${ }^{3}$ Brighton and Sussex Medical School, University of Sussex, UK, \\ ${ }^{4}$ College of Pharmacy, King Saud University, Riyadh, Saudi Arabia \\ ${ }^{5}$ Institute of Cancer and Genetics, School of Medicine, Cardiff University, UK
}

\begin{abstract}
Acetylsalicylic acid, or aspirin, is one of the most common non-steroidal anti-inflammatory drugs, which has been shown to have anti-cancer effects. However, high doses are needed making it unsuitable as an oncology agent. We have previously reported increased potency in a series of hydroxybenzoate zinc (HBZn) aspirin analogues. Here we show that 3-hydroxybenzoate magnesium (3-HBMg) and 4-hydroxybenzoate magnesium (4-HBMg) aspirin derivatives showed cytotoxic effects at doses as low as $1 \mathrm{mM}$. At these concentrations, 3-HBMg and 4-HBMg aspirin increased the level of caspase-3, p53, Bax and decreased the expression of the anti-antiapoptotic protein, Bcl-2, in HT-1080 Human fibrosarcoma cells.
\end{abstract}

\section{Introduction}

Hydroxybenzoic acids are a group of phenolic compounds (Figure 1), this family includes the common drug, acetylsalicylic acid or aspirin. Previous research has clearly indicated that aspirin and other salicylates can reduce risk of large bowel cancer [1-2]. In addition, salicylic acid and acetylsalicylic acid, have common side effects e.g. inhibition of platelet aggregation and stomach lining erosion due to their acidity. Therefore, the several attempts were carried out to design derivatives that focus on improving aspirin efficacy. Our previous research indicated that the designed new salicylate analogues reduced the effective dose of aspirin and induced apoptosis in different cell lines, including fibrosarcoma, breast cancer, and primary chronic lymphatic leukaemia (CLL) [3-6]. These compounds include hydroxybenzoate $\mathrm{Na}, \mathrm{Ca}$, and $\mathrm{Zn}$, (Figure 1), 4-HBZn was the most effective anti-cancer agent $[4,6]$. In this respect, zinc 4-HBZn reduced cell viability, arrested cell cycle in G0/G1 and regulated apoptosis via intrinsic pathway [3,7]. In addition, 4-HBZn synergized with the purine nucleoside analogue fludarabine [8]. Table 1 shows the rank order of the results obtained when HT-1080 human fibrosarcoma and primary CLL cells were treated with a range of hydroxybenzoate analogues. The aim of the current research was to investigate in vitro the pharmacological effect of $3-\mathrm{HBMg}$ and 4-HBMg (Figure 1) in HT-1080 Human fibrosarcoma cells.

Table 1. Summary of pharmacological properties in vitro $[4,9,10,11]$

\begin{tabular}{|l|l|l|}
\hline & Hydroxybenzoate metal compounds & Results \\
\hline $\begin{array}{l}\text { Cell viability } \\
\text { results }\end{array}$ & $\begin{array}{l}\text { 2-HBNa, 2-HBLi, 2-HBCa and 2-HBZn } \\
\text { 3-HBNa, 3-HBLi, 3-HBCa and 3-HBZn } \\
\text { 4-HBNa, 4-HBLi, 4-HBCa and 4-HBZn } \\
\text { (as shown in Figure 1) }\end{array}$ & $\begin{array}{l}\mathrm{HBNa} \text { and } \mathrm{HBLi}<\mathrm{HBCa}< \\
\text { 2-HBM<3-HBM }<4-\mathrm{HBM}\end{array}$ \\
\hline Morphology & $\begin{array}{l}\text { Showed apoptotic with no } \\
\text { necrotic cell death }\end{array}$ \\
\hline
\end{tabular}

\section{Materials and methods}

3-HBMg and 4-HBMg was obtained from Cardiff Medical School, UK. Epithelial cancer cell lines HT-1080 were obtained from ATCC (Manassas, VA).

\section{Cell culture}

Cell culture for HT-1080 cells were conducted at $37^{\circ} \mathrm{C}$ in a humidified atmosphere con- taining 5\% CO2 [9-11]. Cells were cultured in a RPMI-1640 medium. The medium contained GlutaMAX, $25 \mathrm{mmol} / \mathrm{L}$ HEPES buffer (Sigma-Al-drich, UK), 10\% foetal bovine serum (FBS) (Sigma- Aldrich, UK) and $1 \%$ penicillin $(10,000 \mathrm{U} / \mathrm{mL}$; Sigma- Aldrich, UK).

\section{Determination of cell viability by MTT assay}

HT-1080 cells were seeded into 96-well plates at a density of 2.6 $\times 104 \mathrm{cell} /$ well in $90 \mu \mathrm{L}$ optimized medium. The cells were allowed to settle for $24 \mathrm{~h}$ before treated with individual dose of $3-\mathrm{HBMg}$, and 4-HBMg, i.e., $0,0.1,0.15,0.2,0.4,0.6,0.8$ and $1 \mathrm{mM} / \mathrm{L}$. The treated cells were allowed to grow for $48 \mathrm{~h}$. At the end of the incubation period and dose point, $110 \mu \mathrm{L}$ of $0.22 \mu \mathrm{m}$ filter-sterilized, $5 \mathrm{mg} / \mathrm{mL} 3$-(4,5-dimethyl thiazol-2-yl)-2,5-diphenyltetrazolium bromide (MTT) (Sigma-Aldrich, $\mathrm{UK}$ ) was added at a temperature of $37^{\circ} \mathrm{C}$. The 96 -well plate was kept in the dark for $2 \mathrm{~h}$ before the medium containing MTT was removed. 100 $\mu \mathrm{L}$ dimethyl sulphoxide (DMSO) obtained from Ajax Finechem Pty

*Correspondence to: Jassem G Mahdi, Cardiff School of Medicine, Cochrane Medical Education Centre, Heath Park, UK, E-mail: mahdij2@cardiff.ac.uk

Key words: hydroxybenzoate magnesium analogues, HT-1080 human cell, caspase-3, p53, Bax, Bcl-2

Received: July 10, 2019; Accepted: August 09, 2019; Published: August 13, 2019 


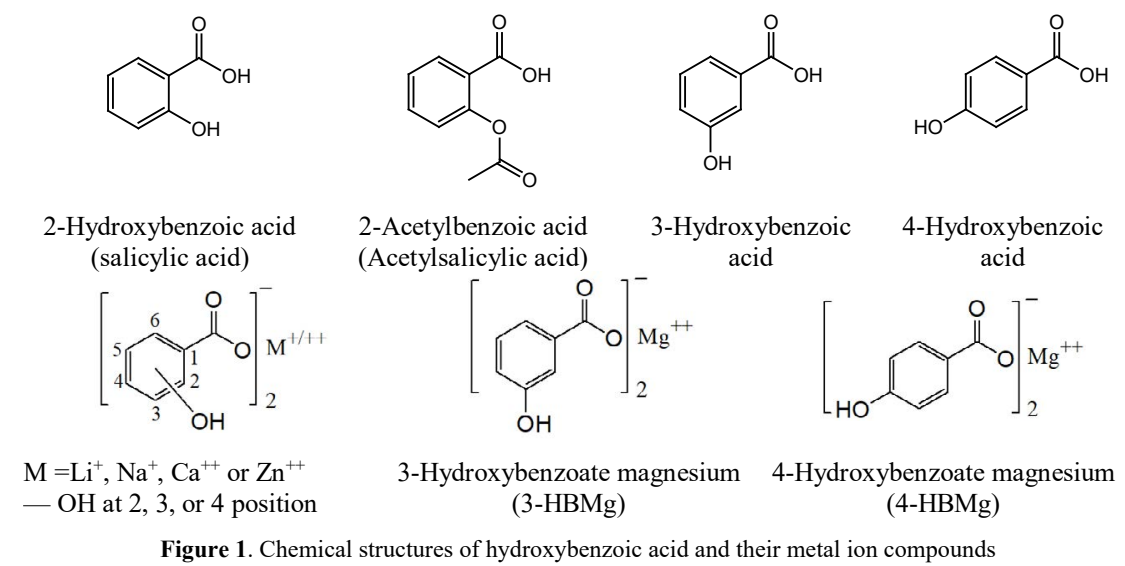

Ltd, Australia, was added to dissolve the formasane crystals. The 96well plates were shaken for $15 \mathrm{~min}$ in the dark to dissolve the formasane crystals. The optical density (OD) of each treatment was measured at $570 \mathrm{~nm}$ using LabSystems Multiskan EX Version 3.0 (Thermo Lab systems, Helsinki, Finland). Each experiment was performed in four replicates. The optical densities were normalized according to the control [11].

\section{Determination of apoptotic proteins expression by western blot}

HT- 1080 cells $(6 \times 105$ cell $/ \mathrm{mL})$ were seeded in T-100 flask, cultured and treated with $3-\mathrm{HBMg}$ and $4-\mathrm{HBMg}$ compounds $(0.0,0.2,0.6$ and $1.0 \mathrm{mM} / \mathrm{L}$ ) for 48 hours, as described in the previous section. The medium was removed, and the cells were washed with cold PBS to remove the medium. Subsequently, RIPA buffer $(150 \mathrm{mmol} / \mathrm{L}$ sodium chloride $(\mathrm{NaCl}), 2 \mathrm{mmol} / \mathrm{L}$ ethylenediaminetetraacetic acid (EDTA), $50 \mathrm{mmol} / \mathrm{L}$ Tris- $\mathrm{HCl}, \mathrm{pH} 7.5)$ and lysis buffer (1\% deoxycholic acid and 1\% NP-40) were added. Protease inhibitor cocktail tablets (Bio-Rad Laboratories, USA) were also added. The cell lysates were then centrifuged at 12,000 $\times \mathrm{g}$ for $15 \mathrm{~min}$. The supernatant was further centrifuged at $4^{\circ} \mathrm{C}$ at $16,000 \times \mathrm{g}$ for $5 \mathrm{~min}$ to obtain a clear solution of the protein mixture. The protein mixture was used to measure the expression of caspase-3, p53, Bcl-2 and Bax by Western blotting using glyceraldehyde-3phosphate dehydrogenase (GAPDH) as an internal antibody control. Total cell lysate protein doses were determined by assay dye (Bio-Rad Laboratories, USA) and absorption was measured at $595 \mathrm{~nm} .60 \mu \mathrm{g}$ of the extracted protein and GAPDH internal antibody control on sodium dodecyl sulfate (SDS) were loaded to $4 \%-12 \%$ Bistrisacrylamide gel in 3-(N-Morpholino) propanesul- fonic acid (NuPAGE MOPS) running buffer (Invitrogen ${ }^{\mathrm{Tm}}$ Life Technologies, Scotland, UK). After running the gel at $75 \mathrm{~V}$ for 3 hours at room temperature, the resolved proteins were transferred onto a nitrocellulose membrane (Sigma-Aldrich, UK). The membranes were first incubated with an appropriate primary antibody (caspase-3, p53, Bcl-2, Bax, or GAPDH as a loading control and internal standard), followed by peroxidase conjugated anti-mouse IgG antibody (Sigma-Aldrich, UK). The membranes were washed and developed using a chemiluminescent reagent (Amersham, UK) prior to exposure to photographic films. The protein bands' intensities were scanned and quantified using a densitometer [11].

\section{Determination of apoptotic protein by annexin- $\mathrm{V}$ assay}

HT-1080 cells $(1.37 \times 105)$ were seeded into 6-well plates containing coverslips $(30 \mathrm{~mm}$ diameter) placed into the centre of 6-well plates. HT-1080 cells were allowed to grow for 48 hours. After 24 hours, the medium was replaced with fresh medium containing the different doses of $3-\mathrm{HBMg}$ and 4 -HBMg. (0.0, 0.2, 0.6 and $1 \mathrm{mM})$. After 48 hours, cells were treated with fluorescein isothiocyanate (FITC)-labelled annexin- $\mathrm{V}(2 \mu \mathrm{l})$ for $15 \mathrm{~min}$ and then with propidium iodide $(2.5 \mu \mathrm{l})$ for $5 \mathrm{~min}$ in the dark. Slides were then examined using a fluorescence microscope. 3 random fields, each of 100 cells, were counted per slide and the percentage of apoptotic cells was calculated based on number of cells that showed nuclear morphology changes [12].

\section{Statistical analysis}

Data obtained in these experiments represent an average of three replicates which were statistically analysed using Graphpad Prism 5.0 software (Graphpad Software Inc., San Diego, CA, USA)

\section{Result and discussion}

Both 3-HBMg and 4-HBMg compounds induced dose-dependent growth inhibition in HT-1080 Human fibrosarcoma cells line (Figure 2). Using MTT cell viability assay indicated that the maximum level of cell viability reduction of $3-\mathrm{HBMg}$ and $4-\mathrm{HBMg}$ was 50.5 and $36.3 \%$ respectively at $1 \mathrm{mM}$ dose. In contrast, the minimum level of reduction in HT- 1080 cell viability were $\%$ and $20.2 \%$ when $0.1 \mathrm{mM} 3-\mathrm{HBMg}$ and 4-HBMg respectively were incubated for 48 hours.

Generally, adding different metal ion to hydroxybenzoic acids improved cytotoxicity between 3 to 5.6 -fold in different cell lines, including Hela cells, HT-1080 human fibrosarcoma cells, and Caco-2 cells [12]. Similar results were obtained when 2-, 3-, and 4-hydroxybenzoate calcium were incubated with different cell lines [10-11].

In order to see the effects of different doses of 3-HBMg and 4-HBMg on the manipulation of apoptosis-related proteins, the p53 tumour suppressor, caspase- 3 and Bax pro-apoptotic protein, and the antiapoptotic $\mathrm{Bcl}-2$ proteins were analysed by Western plots electrophoresis assay.

Figures 3 and 4 shows the immunoblots of the four analysed apoptosis-related proteins. The results indicate that the treatment of HT-1080 cell line with individual $3-\mathrm{HBMg}$ and $4-\mathrm{HBMg}$ compound increased the level of Bax and reduced the corresponding anti-apoptotic Bcl-2 in dose-dependent manner in HT-1080 cells. Our previous investigation, when hydroxybenzoate calcium and hydroxybenzoate zinc was used similar results were obtained $[7,11]$. In addition, when HT-1080 cells were treated with different doses of $3-\mathrm{HBMg}$ and 4-HBMg compounds for 48 hours, both caspase- 3 and p53 increased which may indicate that the cell death in HT-1080 cells is associated with the intrinsic pathway. 


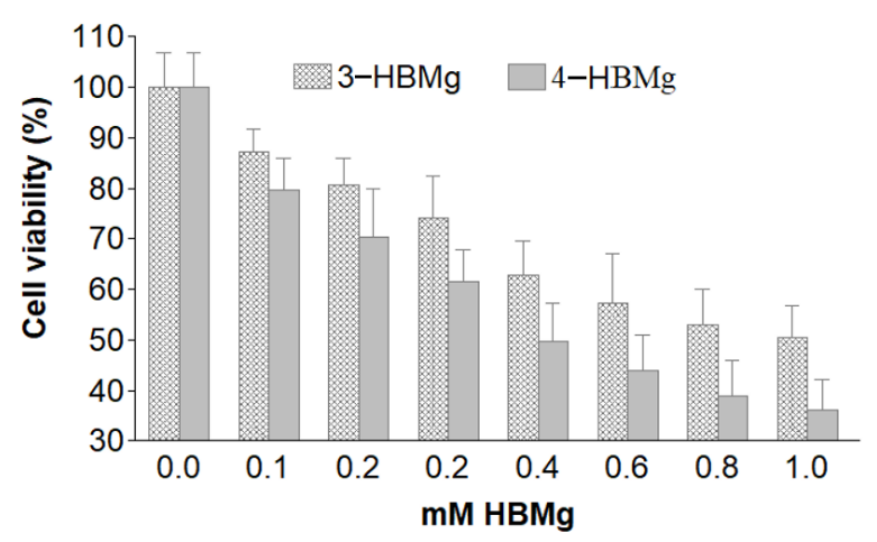

Figure 2. Cell viability of 3-HBMg and 4-HBMg-treated HT-1080 for 48 hours using data derived from MTT viability assay in 4 replicates.
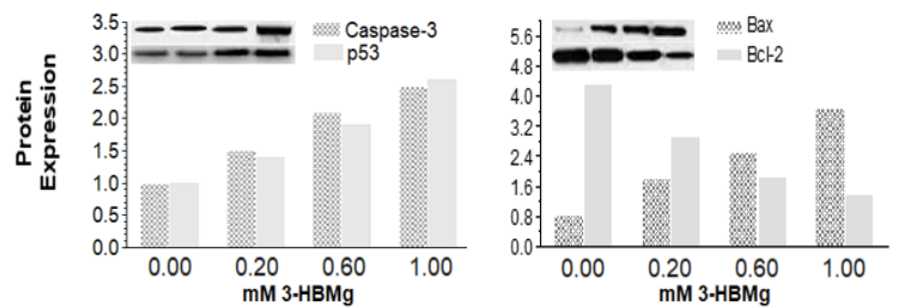

Figure 3. Apoptosis-related expressed proteins in HT-1080 cells due to the treatments with different doses of 3-HBMg for 48 hours
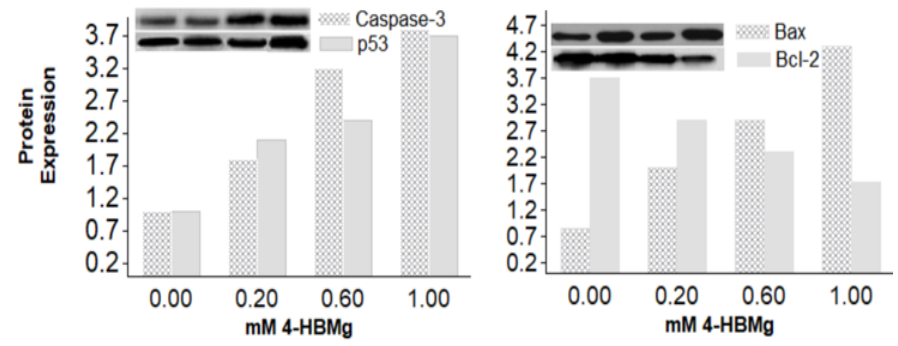

Figure 4. Apoptosis-related expressed proteins in HT-1080 cells due to the treatments with different doses of 4-HBMg for 48 hours

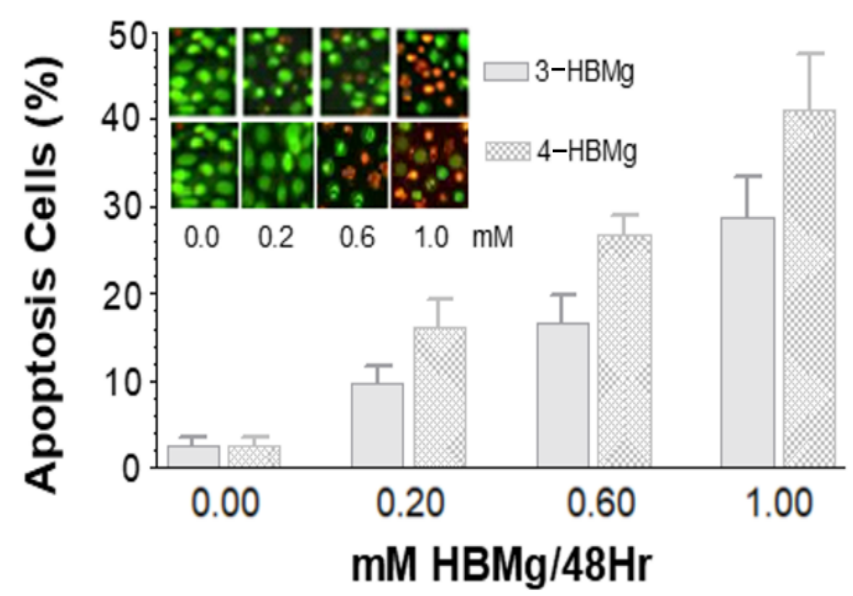

Figure 5. Immunohistochemistry of treated HT-1080 cells with different doses of 3and 4-HBMg. Annexin V was used to label the flagged-out phosphatidylserine when cells undergo apoptotic cell death. Data were derived from 3 slides, in which both labelled apoptotic and viable HT-1080 cells were counted then percentage of apoptotic cells were calculated $(\%=$ apoptotic cells/total cells present in the slide). Treatment of HT-1080 cells with $0.2,0.6$ and $1 \mathrm{mM} 3-\mathrm{HBMg}$ and $4-\mathrm{HBMg}$ were significantly different from the control sample at $p=0.001$. Different doses were significantly different from each other at $p=0.05$.
In order to investigate whether different concentration of $3-\mathrm{HBMg}$ and $4-\mathrm{HBMg}$ induced apoptosis in HT-1080 cells, the immunohistochemical assay was used to label the flag out of the phosphatidylserine. Figure 5 shows the morphological results of apoptotic HT-1080 cells which was labelled by annexin V. These results are in line with the other results in which the induction of apoptosis by 3-HBMg and 4-HBMg in HT-1080 cells increased in dose-dependent manner.

\section{Conclusion}

The results from the western blot and immunohistochemical assays indicated that $3-\mathrm{HBMg}$ and $4-\mathrm{HBMg}$ induced apoptosis in HT-1080 cells in a dose-dependent manner.

\section{References}

1. Elwood PC, Gallagher AM, Duthie GG, Mur LA, Morgan G (2009) Aspirin, salicylates, and cancer. The Lancet 373: 1301-1309. [Crossref]

2. Abdelrahim M, Safe S (2005) Cyclooxygenase-2 inhibitors decrease vascular endothelial growth factor expression in colon cancer cells by enhanced degradation of Sp1 and Sp4 proteins. Mol Pharmacol 68: 317-329. [Crossref]

3. Wolfe MM, Lichtenstein DR, Singh G (1999) Gastrointestinal toxicity of nonsteroidal antiinflammatory drugs. $N$ Engl J Med 340: 1888-1899. [Crossref]

4. Mahdi JG, Pepper CJ, Alkarrawi MA, Mahdi AJ, Bowen ID (2010) Sub-millimolar concentration of the novel phenol-based compound, 2-hydroxy benzoate zinc, induces apoptosis in human HT-1080 fibrosarcoma cells. Cell Prolif 43: 95-102. [Crossref]

5. Mahdi J, Al-Musayeib N, Mahdi E, Pepper C (2013) Pharmacological importance of simple phenolic compounds on inflammation, cell proliferation and apoptosis with a special reference to $\beta$-D-salicin and hydroxybenzoic acid. Eur J Inflamm 11: 327-336.

6. Mahdi JG, Mahdi EJ, Al-Hazzaa A, Pepper CJ (2013) The Effect of Hydroxybenzoate Lithium Complexes in Inducing Apoptosis in HT-1080 Human Fibrosarcoma Cells. Journal of Cancer Research 2013: ID 203659.

7. Pepper C, Mahdi JG, Buggins AG, Hewamana S, Walsby E, et al. (2011) Two novel aspirin analogues show selective cytotoxicity in primary chronic lymphocytic leukaemia cells that is associated with dual inhibition of Rel A and COX-2. Cell Prolif 44: 380-390. [Crossref]

8. Mahdi JG, Alkarrawi MA, Mahdi AJ, Bowen ID, Humam D (2006) Calcium salicylatemediated apoptosis in human HT-1080 fibrosarcoma cells. Cell Prolif 39: 249-260. [Crossref]

9. Mahdi E, Buggins AG, Jones CH, Walsby EJ, Mahdi A, et al. (2014) A novel aspirin analog resensitizes primary human leukemia cells to fludarabine via the selective inhibition of prostaglandin biosynthesis and repression of Nf-kb target genes: 39 . British Journal of Haematology 165: 20.

10. Mahdi JG, Mahdi AJ, Mahdi EJ, Abdulsatar A, Mahdi AJ, et al. (2015). Morphological modulation of human fibrosarcoma HT-1080 cells by hydroxybenzoate compounds during apoptosis. Adv Mod Oncol Res 1: 68-75.

11. Mahdi JG, Al-Musayeib NM, Mahdi EJ, Abdulsatar AJ, Pepper CJ (2014) The antiproliferation and pro-apoptosis of hydroxybenzoate calcium complexes in HT-1080 human fibrosarcoma cells. European Journal of Oncology 19: 21-33.

12. Merghani NM, Al Hazzaa A, Mahdi EJ, Manning AJ, Buggins AG, et al. (2015) The effect of hydroxybenzoate calcium compounds in inducing cell death in epithelial breast cancer cells. Adv Mod Oncol Res 1: 122-131.

Copyright: (C)2019 Manning AJ. This is an open-access article distributed under the terms of the Creative Commons Attribution License, which permits unrestricted use, distribution, and reproduction in any medium, provided the original author and source are credited. 